\title{
KEGIATAN PENGOLAHAN BAHAN PUSTAKA DI DINAS KEARSIPAN DAN PERPUSTAKAAN KOTA MATARAM
}

\author{
LIBRARY MATERIAL PROCESSING ACTIVITIES AT THE ARCHIVES AND LIBRARY \\ DEPARTEMENT OF MATARAM CITY
}

\author{
Titin Agustina ${ }^{1}$, Nurul Fikriati Ayu H. ${ }^{2}$, Hirma Susilawati ${ }^{3}$ \\ 1,2,3 Universitas Muhammadiyah Mataram \\ 2Email: nufihapsari@gmail.com \\ ${ }^{3}$ Email: hirmasusilawati4@gmail.com
}

\begin{abstract}
ABSTRAK/ ABSTRACT
Perpustakaan memiliki begitu banyak peran untuk memenuhi kebutuhan terutama kebutuhan pengetahuan. Namun di era modern ini sumber bacaan banyak terpampang di internet yang membuat masyarakat lebih memilih mengakses bahan bacaan yang ada di internet dari pada harus mencari di tiap-tiap rak buku perpustakaan. Perpustakaan seakaan dijadikan pilihan kedua apa bila informasi yang ingin dicari tidak dapat ditemukan di internet. Inilah yang membuat kesadaran masyarakat tentang pentingnya peran perpustakaan sangat berkurang Sehgga didperlukannya perbaikan dalam pengelolaan bahan pustaka di Dinas Kearsipan dan Perpustakaan Kota Mataram. Adapun metode yang digunakan untuk adalah dengan cara memperbaiki kegiatan pengelolaan bahan pustaka di Perpustakaan kota Mataram. Semua tahapan kegiatan pengabdian masyarakat di Dinas Kearsipan dan Perpustakaan Kota Mataram tela dilaksanakan dan menghasilkan luaran diantaranya yaitu pelaksanaan pengolahan bahan pustaka mulai dari Inventaris, pemberian stampel, klasifikasi, katalogisasi, labeling dan shelving.
\end{abstract}

Kata Kunci : perpustakaan, pengelolaan, bahan pustaka

Submited : 28 Oktober 2021

Revision : 01 November 2021

Accepted : 05 November 2021

\section{A. PENDAHULUAN}

Perpustakaan merupakan bangunan yang berisikan berbagai macam informasi dalam bentuk koleksi, baik koleksi tercetak maupun koleksi non cetak, dan yang dimana perpustakaan ini dapat dikatakan sebagai jantungnya pendidikan. Hal ini dikarenakan perpustakaan merupakan sumber ilmu yang paling banyak menyokong kebutuhan ilmu pengetahuan dalam bidang pendidikan.

Pada saat ini perpustakaan masih dipandang sebelah mata kerena banyak dari masyarakat yang belum mengetahui apa fungsi dari perpustakaan itu sendiri. Kebanyakan dari masyarakat memandang perpustakaan sebagai tempat yang 
membosankan sehingga minat membacanyapun kurang. Tanpa sadar dari minat baca yang kurang inilah yang membuat masyarakat sama sekali tidak mengetahui pentingnya fungsi perpustakaan. Masyarakat luas lebih sering berpikir bahwa perpustakaan merupakan sumber kebutuhan sesaat, bukan kebutuhan jangka panjang yang memiliki peran penting diwaktu yang akan datang.

Perpustakaan memiliki begitu banyak peran untuk memenuhi kebutuhan terutama kebutuhan pengetahuan.Perpustakan sejak dahulu dipercaya dapat membantu semua kalangan untuk menemukan berbagai sumber informasi. Namun di era modern ini sumber bacaan banyak terpampang di internet yang membuat masyarakat lebih memilih mengakses bahan bacaan yang ada di internet dari pada harus mencari di tiap-tiap rak buku perpustakaan. Perpustakaan seakaan dijadikan pilihan kedua apa bila informasi yang ingin dicari tidak dapat ditemukan di internet. Inilah yang membuat kesadaran masyarakat tentang pentingnya peran perpustakaan sangat berkurang. Dalam hal ini peran dari pustakawan, orang tua, dan beberapa tenaga pendidik mampu lebih serius untuk memperkenalkan perpustakaan. Samasama memperkenalkan pentingnya membaca dan banyaknya kegunaan perpustakaan sejak dini, agar anak terbiasa tentang hal-hal yang berkaitan dengan perpustakaan.Salah satu bentuk peran pustakawan atau para pendidik adalah mengajak siswa atau mahasiswa meluangkan waktu untuk melakukan kegiatan atau aktivitas diperpustakaan sehingga dengan kegiatan kecil seperti membaca dapat membantu untuk meningkatkan minat baca dan ilmu pengetahuan serta kesadaran tentang peran penting perpustakaan untuk ilmu pengetahuan.

Perpustakaan sebenarnya merupakan sebuah wadah atau fasilitas yang memudahkan masyarakat untuk menemukan hal-hal yang ingin dicari atau dipelajari dengan sesuka hati tanpa harus membeli atau membayar jasa tenaga seseorang untuk mencari ilmu. Tapi kebanyakan masyarakat, kaum pendidikan,lebih kuhususnya mahasiswa cenderung mengunjungi perpustakaan hanya ketika memiliki keperluan khusus. Hal yang menonjol adalah ketika mahasiswa dihimpit tuntutan materi skripsi sehingga menjadikan perpustakaan sebagai kebutuhan sesaat dan tidak lagi sebagai wadah untuk mencari sumber ilmu lain di luar mata kuliahnya. 
Peran yang paling dibutuhkan disini adalah pustakawan terlebih lagi bagi calon-calon pustakawan agar untuk lebih jelih lagi melihat masalah masalah yang ada pada masyarakat serta lebih kreatif lagi untuk membangun kesadaran masyarakat tentang pentingnya peran perpustakaan. Setidaknya dengan usaha yang dilakukan oleh calon pustakawan dapat membantu meningkatkan mutu pendidikan melalui peran perpustakaan pada generasi-generasi yang akan datang.

\section{B. METODE}

Pelaksanaan kegiatan ini dilaksanakan di Dinas Kearsipan dan Perpustakaan Kota Mataram. Waktu pelaksanaan mulai tanggal 16 Maret 2021 hingga 30 April 2021 atau selama 1,5 bulan. Metode yang digunakan dalam melakukan kegiatan ini dengan terjun langsung terlibat dalam kegiatan pelayanan di Dinas Kearsipan dan Perpustakaan Kota Mataram.

\section{HASIL DAN PEMBAHASAN}

Dinas Kearsipan dan Perpustakaan Kota Mataram adalah salah satu organisasi lembaga teknis daerah yang dibentuk berdasarkan amant undang-undang tata kelola pemerintah daerah. Dengan demikian eksistensi keberadaan dinas kearsipan dan perpustakaan Kota Mataram menjadi suatu keharusan sebagai lembaga penyedia informasi bagi pengguna dalam mengakses informasi berdasarkan Perda No. 5 Tahun 2008 tentang pembentukan susunan organisasi lembaga-lembaga teknis Daerah Kota Mataram, setra di sempurnakan kembali dengan peraturan Walikota Mataram No 57 Tahun 2016 tentang kedudukan dan tugas pokok dan fungsi dinas kearsipan dan perpustakaan Kota Mataram, susunan organisasi Dinas Kearsipan dan Perpustakaan (DIARPUS) Kota Mataram.

Untuk meningkatkan kemajuan perpustakaan agar lebih diketahui oleh masyarakat umum, maka Dinas Kearsipan dan Perpustakaan Kota Mataram mengadakan berbagai kegiatan antara lain: 


\section{Bidang Pengolahan}

Menurut P. Sumardji (1993: 25) mengatakan bahwa kegiatan pengolahan bahan koleksi adalah kegiatan mempersiapkan bahan koleksi yang telah diperoleh, agar dengan mudah dapat diatur di tempat - tempat atau rak - rak penyimpanan sehingga memudahkan pula untuk dilayankan kepada para pemakai koleksi perpustakaan.Tujuan dari pengolahan bahan pustaka ini yaitu agar memudahkan pemusataka dalam menemukan koleksi yang dibutuhkan. Langkah - langkah dalam peengolahan bahan pustaka yaitu:

Adapun proses pengolahan yang dilakukan adalah sebagai berikut.:

a. Inventaris

Inventaris adalah pencatatan bahan pustaka kedalam buku induk yang di dapatkan baik dari pembelian ataupun hadiah. Yang harus dicatat dalam buku induk yaitu :

1) Tanggal masuk

2) Nomor judul dan induk

3) Judul buku

4) Pengarang

5) Tahun terbit

6) Penerbit

7) Asal buku (pembelian, hadiah atau sumbangan)

8) Harga

9) Cetakan

10) Keterangan

Pembagian sumber buku di Dinas Kearsipan dan Perpustakaan Kota Mataram menggunakan kode PB untuk pembelian dan SB untuk hadiah ataupun sumbangan. Kegiatan inventaris yang meliputi pegecekan bahan pustaka dalam keadaan baik dan lengkap, lalu pemberian stempel dan yang dimana ada dua jenis stempel yang digunakan yaitu stempel kepemilikan dan 
stempel rahasia. Dalam pemberian stempel ini, stempel kepemilikan pada halaman depan dan halaman belakang tanpa mengganggu teks, sedangkan untuk pemberian stempel rahasia pada halaman 15 di setiap buku. Serta pencatatan nomor buku masuk pada buku induk yang memiliki kode sb untuk sumbangan ataupun hadiah dan kode pb untuk pembelian. Adapun yang dicatat dalam buku induk adalah tanggal, nomor judul, nomor induk, judul buku, pengarang, tahun terbit, penerbit, asal, harga, cetakan serta keterangan.

b. Pemberian stempel Perpustakaan Kota Mataram

Pemberian stempel perpustakaan bertujuan untuk memberikan identitas tentang koleksi bahan pustaka yang dimiliki suatu badan atau instansi. Dalam pemberian stempel atau pengecapan ini terdiri dari stempel hak milik sesuai dengan standar Perpustakaan. Adapun tata cara dalam pemberian stempel pada bahan pustaka yaitu:

1) Di halaman depan

2) Halaman rahasia di hal 15

3) Halaman terakhir

4) Pada prinsip stempel atau pengecapan tidak boleh mengganggu teks yang ada didalam isi buku.

c. Klasifikasi

Klasifikasi adalah suatu kegiatan mengelompokkan benda yang memiliki ciri yang sama dan sekaligus memisahkan benda yang tidak sama (Upriadi, 2012:4). Klasifikasi, sebelum proses pengklasifikasi, pustakawan pertama-tama memilah buku sesuai dengan judul, daftar isi serta pendahuluannya agar memudahkan dalam mencari subyek buku agar memudahkan dalam melakukan pekerjaan selanjutnya. Sebagian besar buku yang paling banyak diolah pada bulan Februari adalah buku untuk anak-anak, namun ada pula buku untuk remaja ataupun dewasa seperti buku agama, novel, pendidikan dan sosial. 


\section{d. Katalogisasi}

Katalogisasi adalah proses pengolahan data yang disusun secara sistematis dengan tujuan agar memudahkan temu kembali bahan pustaka yang dicari. Proses katalogisasi yang dilakukan di Dinas Kearsipan dan Perpustakaan Kota Mataram sudah terbilang maju, dikarenakan system yang di gunakan adalah INLISLITE versi 3.2. Dalam system ini, sudah terdapat berbagai macam program-program seperti akuisisi, entri katalog, entri koleksi, keanggotaan serta sirkulasi. Selain itu pula, pada label sudah tersedia nomor barcode serta warna sesuai dengan nomor kelas sudah langsung tersedia di dalam program tersebut setelah kita selesai mengentri data koleksi.

Adapun tahapan entri data koleksi pada aplikasi inlislite:

1) Pastikan xampp-control telah berjalan di masing-masing server lokasi inlislite Perpustakaan Umum Kota Mataram.

2) Buka aplikasi dimasing-masing 192.168.8.15/inlislite-3.2.

3) Masukkan usernme: inlislite dan pasword kemudian tekan sign in.

4) Pada tampilan dashboard back office, tekan menu katalog, pilih sub menu entri katalog.

5) Pilih jenis bahan perpustakaan monograf (buku, laporan, dll).

6) Isi area judul (judul utama, anak judul, dan penanggungjawab), untuk kolom penanggung jawab isilah dengan nama pengarang, editor/penyunting atau badan koorporsi.

7) Isi area tajuk pengarang dengan memperhatikan kaidah-kaidah penulisan yang benar, jika pengarang merupakan nama badan (lembaga, institusi dan sejenisnya), maka ubah pilihan tajuk pengarang utama.

8) Isi area penerbitan yang mencakup tempat terbit, penerbit dan tahun terbit.

9) Isi area deskripsi fisik yang mencangkup jumlah, keterangan ilustrasi (jika terdapat gambar, grafik dan sejenisnya), dimensi (hanya ukuran tinggi tidak termasuk lebar) dan bahan sertaan (CD, lembaran lepas).

10) Selanjutnya isi keterangan edisi dan subjek.

11) Isi area catatan (bisa berupa abstrak/anotasi, catatan disertasi, catatan bibliografi, catatan isi atau catatan umum) pilihah sesuai catatan yang akan 
dimuat, dan bisa diisi lebih dari 1 catatan. Kemudian pilih bahasa digunakan dalam isi bahan perpustakaan, bentuk karya tulis dan kelompok sasaran.

12) Isi area okasi koleksi darang jika ada tautan/link untuk menuju konten digital (jika tidak ada bisa dikosongkan), kemudian centang pilihan tampil di OPAC jika akan lansung di tampilkan di OPAC, namun jika tidak dikosongkan tanda centang tersebut.

13) Tampilkan keterangan koleksi/eksemplar, pilih menu tab koleksi, kemudian tekan tombol tambah eksemplar.

14) Isi form data koleksi kemudian simpan.

e. Labeling atau pelabelan

Labeling adalah kegiatan pengolahan bahan pustaka yaitu untuk memberikan pelengkapan buku untuk dapat membantu memberikan kemudahan dalam layanan Perpustakaan ada beberapa pekerjaan labeling yang dapat dilakukan oleh Perpustakaan yaitu:

1) Mencetak buku yang telah tersimpan pada program inlislite versi 3.2.

Penempelan label ini di tempatkan dipunggung buku, kira-kira 3 $\mathrm{cm}$ dari buku bagian bawah dengan ukuran $5 \times 6 \mathrm{~cm}$

2) Menempel kantong buku

Kantong buku biasanya ditempel dalam kulit buku belakang dan bahan yang di pakai biasanya kertas kesting karton manila

3) Memasukkan kartu buku ke kantong buku

4) Kartu buku dimasukan ke dalam kantong buku yang sudah ditempel sebelumnya dengan ukuran lebih kecil dari ukuran kantong buku, yaitu 7 $\mathrm{x} 13 \mathrm{~cm}$, bahan yang biasanya dipakai adalah karton manila

5) Menempel lembar slip pengembalian dan peminjaman ditempatkan pada halaman terakhir buku dan kartu buku yang telah ditempel di punggung buku, dengan ukuran 8 x $15 \mathrm{~cm}$ dengan bahan HVS 
f. Shelving.

Kegiatan ini sangat rutin dilakukan dengan tujuan untuk memastikan buku sudah berada pada rak sesuai dengan nomor kelas. Kegiatan ini dilakukan ketika pagi hari sebelum pengunjung datang.

\section{Bidang Pelestarian bahan pustaka}

Tujuan pelestarian bahan pustaka adalah melestarikan kandungan informasi bahan pustaka dengan alih bentuk menggunakan media lain atau melestarikan bentuk aslinya selengkap mungkin agar bahan pustaka itu dapat digunakan secara optimal dalam jangka waktu yang cukup lama.

Adapun kegiatan pelestarian koleksi bahan pustaka meliputi beberapa hal sebagai berikut, yakni memberikan gel pada sisi buku bukan kapur barus. Karena jika menggunakan kapur barus akan menjadikan buku cepat rusak. Pencahayaan dan suhu udara (AC) di sesuaikan dengan aturan yakni dengan menggunakan suhu terkecil. Lampu harus sejajar dengan rak. Menggunakan aturan penaruhan buku yang berjarak 3 jari. Melakukan penjilidan dan laminasi pada buku-buku baru agar meminimalisir kerusakan pada bahan pustaka. Melakukan re-produksi pada bahan pustaka serta melakukan berbagai macam pencegahan faktor - faktor perusak koleksi.

\section{Bidang Pelayanan}

Menurut Sutarno NS (2004: 162) layanan perpustakaan adalah merupakan kelanjutan kegiatan pengadaan, dan pengolahan, yakni setelah koleksi bahan pustaka seleksi diolah (diproses).

Setelah koleksi bahan pustaka Perpustakaan Kota Mataram selesai dalam pengolahan, lalu bahan pustaka tersebut dipindahkan kebagian layanan untuk dilayankan, namun sebelumnya pada kegiatan ini kami mengentri data koleksi bahan pustaka tersebut ke dalam bibliografi, kemudian siap untuk dipinjamkan.

Selain itu pada bagian pelayanan ini juga kami melakukan pelayanan pembuatan kartu anggota perpustakaan,untuk dapat terdaftar sebagai anggota perpustakaan Kota Mataram membuat persyaratan yaitu membawa KTM / KTP dan mengisi surat permohonan anggota perpustakaan. Kemudian kami memasukan data pemohon keanggotaannya. 


\section{Pembuatan Kartu Bebas Pinjam Pustaka}

Surat keterangan bebas pustaka ini diberikan untuk kepentingan pesyaratan yudisium, sebagai bukti tidak mempunyai tanggungan pinjaman di perpustakaan. pembuatan surat keterangan ini dilayani di Dinas Kearsipan dan Perpustakaan Kota Mataram. Syarat memperoleh surat keterangan ini ada:

a. Melampirkan foto copy KTP Kota Mataram dan Kartu Pealajar/Mahasiswa/ sebanyak 1 (satu) lembar.

b. Kalau tidak ada KTP Mataram menggunakan Surat Keterangan Domisili

c. Bagi Mahasiswa yang semester 6 (enam) keatas harus melampirkan Surat Keterangan Masih Kuliah dari Fakultas

\section{SIMPULAN}

Dinas Kearsipan dan Perpustakaan Kota Mataram mengalami penurunan pengunjung dikarenakan pada adanya pandemic covid 19, sehingga dibutuhkan peran pustakawan dalam menemukan informasi. Adanya pengadaan koleksi diharapkan sesuai dengan kebutuhan informasi pengguna di Dinas Kearsipan dan Perpustakaan Kota Mataram. Perpustakaan kota Mataram menggunakan aplikasi INLISLITE versi 3.2 , dengan adanya system aplikasi berbasis Integrated Library System ini dapat memudahkan pustakawan dalam mengelola bahan pustaka serta membantu memaksimalkan pelayanan. Peranan pengembangan perpustakaan sangat diperlukan untuk lebih meningkatkan peran serta fungsi perpustakaan menjadi jauh lebih baik. 


\section{DAFTAR PUSTAKA}

Sumardji, P. (1993). Mengelola Perpustakaan. Yogyakarta: Kanasius

Sutarno, NS. (2006). Perpustakaan dan Masyarakat. Jakarta: Sagung Seto

Profil Perpustakaan Kota Mataram (http://diarpus.mataramkota.go.id/) Diakses pada tanggal 30 Oktober 2021 Jam 10:30 Wita. 